\title{
Peat Swamp Forest Degradation: Impacts, Affected Communities and Losses
}

\author{
Nur Arifatul Ulya ${ }^{1,}$, Efendi Agus Waluyo ${ }^{1}$, Sri Lestari ${ }^{1}$ and Bambang Tejo Premonoi ${ }^{1}$ \\ ${ }^{1}$ Environment and Forestry Research and Development Institute of Palembang, Jl. Kol. H. Burlian \\ Km. 6,5 Punti Kayu, Palembang, Indonesia
}

\begin{abstract}
Degradation of peat swamp forest have locally, regionally and regionally impact. This paper presents the impact of peat swamp forest degradation with a focus on the study of communities around peat swamp forest. In-depth interviews were used as a method to identify communities affected by peat swamp forest degradation. Cost of illness, the change of productivity is used as an approach to predict community losses as a result of peat swamp forest degradation. The results of the study show that peat swamp forest degradation has an impact on forest, provincial and regional communities. Peat swamp forest degradation causes a decrease in environmental quality, productivity and various health impacts on communities around the forest. Various economic sectors such as transportation, transportation, trade, tourism, health and education have a negative impact from forest and land fires as a result of peat swamp forest degradation.
\end{abstract}

\section{Introduction}

Forests produce goods and services that provide many benefits for human life. The benefits produced by forests are tangible and intangible. Tangibe benefits from forests that consist of wood and non-timber forest products that traditionally have market prices, are generally traded in traditional markets as commodities. Intangible benefits are related to the ecological functions of forests such as watersheds, soils and flood protection, nutrient cycles, biodiversity and others that are generally undervalued and not traded in conventional markets[1-4]. These benefits are produced by natural forests and plantations, with different compositions [5-8].

Forests in Indonesia from time to time provide various benefits that are important for human survival. Intangible benefits provided by forest resources are in the form of supporting life systems, especially in relation to water management and disaster protection. The benefits of tangible forest resources are shown in part by the contribution of the forestry sector in the national economy.

Indonesia's forest area has contributed to the national economy since the issuance of the Investment Law (Law No. 1/1967) and the Basic Forestry Law/BFL(Law No. 5/1967). In

*Corresponding author: nurarifatululya@gmail.com 
the early 1970s the primary sector contributed $60 \%$ of GDP with exports reaching $94 \%$ of total national exports. During this period the contribution of the agricultural and forestry sectors reached 50\%. Foreign exchange earnings from the forestry sector in the period 1992 - 1997 amounted to US \$ 16.0 billion, or around 3.5 percent of Indonesia's GDP[9]. Since the late of 1990s, the contribution of the forestry sector was declicne, which was allegedly closely related to deforestation and forest degradation in Indonesia.

The impact of peat swamp forest degradation in Indonesia not only felt by communities around the forest as well as on a broader scale, both at the provincial, national and transnational levels. This range of impacts is thought to be closely related to the benefits of peat swamp forests that accepted by community around forest and and away from the forest

This study aims to study the management of peat swamp forest in South Sumatra, degradation of peat swamp forest, identify affected communities and their losses. The discussion is focused on the economic aspects of peat swamp forest degradation for the community at various levels of impact.

\section{Materials and Methods}

Research data was obtained by interviewing respondents and literature study. The value of the loss of the affected community is directly assessed using the cost of illness approach and opportunity cost method[10]arising from peat swamp forest degradation. Peat degradation results in disruption of the environmental protection function of peat swamp forests so that droughts, floods and haze occur. Data from communities affected by peat swamp forest degradation were obtained through case studies on communities around the Peat Hydrological Unit (PHU) Sungai Buntu Kecil - Sungai Hitam. The impact of peat swamp forest degradation on a broader scale is approached by literature study.

\section{Results and Discussions}

\subsection{Forest Utilization in South Sumatra}

Forest benefits for the people of South Sumatra are recorded from the era of the Sriwijaya Kingdom. The river which is asthe result of forest's ecological benefits, became main transportation system for the community since Sriwijaya Kingdom period. [11]provide information that the forests of the Bukit Barisan mountains are springs for rivers that flow to the east coast of South Sumatra which empties into the Malacca Strait.

Crops and forest products (wood, sap, resin, camphor, agarwood, styrax, rattan) are transported through rivers starting from the upstream areas of South Sumatra to downstream and vice versa[12]-[15]. Kajang boats and wooded sailboats made from wood are the main transportation moda in the Sriwijaya Kingdom trade, both in inter-island and foreign trade[13], [14]. Nibung wood (Oncosperma tigilarium), medang and unglen (Eusideroxylon zwagery) are woods used as pillars of stilt houses found in Air Sugihan, Ogan Komering Ilir. The walls of the house are thought to be in the form of woven bamboo or wood[16].

In the era of the Palembang Darussalam Sultanate, forests are still an important ecosystem that supports people's lives and economy. Ecological benefits of forests in the form of Musi River flows and their tributaries are still the main transportation routes. Raft houses, limas houses, stilts and Palaces of the Palembang Darussalam Sultanate use wood as the main raw material. Nibung, medang, unglen, kulim and tembesu wood are the main wood raw materials for stilts and various other buildings[17]. Wood also becomes the main 
raw material for river transportation vehicle [16].[17] added information that the wood used in Palembang was thought to have originated from forests around Palembang and peat swamp forests in Ogan Komering Ilir Regency[13], [18] provide information that nontimber forest products such as resin, camphor, agarwood, styrax, rattan are still the main commodities traded during the Palembang Darussalam Sultanate. Forest management during the Palembang Darussalam Sultanate was in the hands of the clan. Forest management by clan continued until the Village Law was issued in 1979.

Forest management rules during the Dutch colonial period were regulated in Boschordonantie (1927). Forest management in South Sumatra during the Dutch colonial era was not as intensive as forest management in Java and Madura Island. At the beginning of Indonesia independence, boschordonantie was still a reference in forest management in South Sumatra. Logging of natural forest, especially from the peat swamp forest on the east coast, is carried out using a small scale system (persil)[13].

Major changes in forest management in South Sumatra and Indonesia in general occur after the government issues the BFL. Starting in the 1970s, Forest Concession Rights (FCR) began operating in both peat swamp forests along the east coast of South Sumatra and in dryland forests. Logs from the peat swamp forest area in OKI and Musi Banyuasin are exported. The logs from the peat swamp forest in OKI is transported via the river to Borang Island on the Musi River, than trasported overseas by ship[19]providing information that the peatland area on the east coast of OKI in the 1970s was still in covered by natural forest, a logging business was carried out on small scale. Untill 1990s it is assumed $600.000 \mathrm{~m}^{3}$ of wood annually from peat swamp forests in OKI. The clearing of peat swamp forests in OKI is expanding with the development of transmigration settlements. This condition is almost the same for the peat swamp forest area on the east coast of South Sumatra, including Musi Banyuasin Regency.

The development of Industrial Plantation Forests (IPF) at the end of the 1990s was actually aimed at rehabilitating production forests that were not sustainably managed in the era of FCR which were worsed by forest and land fires in 1997/1998. However, contradictions occur when the development of IPF is carried out on peatlands with practices that worsen the degradation of peat swamp forests.[20-22]stated that the development of IPFon peatlands with canal development caused degradation of peatlands.

\subsection{Forest Utilization in South Sumatra}

The exploitation of peat swamp forest on the eastcoast of South Sumatra to produce timber both legally and illegally without the success of replanting causes the opening of forest cover. Infrastructure development related to logging activities, such as roads, rails, and canals, causes severe damage to peat swamp forests [20, 24-26]. Transmigration set tlements along the eastcoast of South Sumatra alsoplay a role in peat land degradation and conversion of forest areas into non-forest areas [13, 20-22].

Peat swampforestswhich are inundated by natural conditions, experience drought due to natural changes or management that drains peat. Peat is actually an organic material that has not been decomposed completely. In the long dry season, degraded peat potentially becomes fuel for forest and peat land fires. This is increasing lycomplex if the condition of degraded peat is converted into cultivation areas that use fire in land preparation. As a result, the frequency of forest fires is increasing when the peat is degraded to become more damaged by recurrent fire [20-22, [24].

Peat land degradation also causes subsidence and carbon emissions. Carbon emissions occur due to subsidence, as well as emissions from peat and vegetation fires[21,24, 30, 31]. Subdidence after drainage on peat lands that managed as Acacia IPF and oil palm 
plantations in the first five years is about $142 \mathrm{~cm}$, of which $75 \mathrm{~cm}$ occur in the first year. After 5 years, the average subsidence rate is $0.7 \mathrm{~m}$ constant at $5 \mathrm{~cm} /$ year. The average carbon loss in the first 5 years is $178 \mathrm{t} \mathrm{CO} 2 \mathrm{eq} / \mathrm{ha}$, and reduced to $73 \mathrm{tCO} 2 \mathrm{eq} /$ ha for the following years. The average carbon loss potential is $100 \mathrm{t} \mathrm{CO} 2 \mathrm{eq} / \mathrm{ha}$ for 25 years [30].

The economic conditions of the communities around peat swamp forests also affect the condition of peat swamp forests. Communities around peat swamp forests generally extract wood, fish and other non-timber forest products. Community dependence on wood causes people to carry out illegal logging which causes over exploitation. The community uses fire in land preparation for cultivation on peatlands[20].

The exploitation of peat swamp forests on the east coast of South Sumatra by FCR, illegal logging, infrastructure development, agriculture, and the construction of IPFs that unsuitable with characteristics of peatlands causes degradation of peat swamp forests in South Sumatra. The degradation of peat swamp forests causes the peat swamp forest ecosystem unable to carry out its ecological functions properly. In the case of peat swamp forests in PHU Sungai Buntu Kecil-Sungai Hitam, the degradation of peat swamp forests causes disturbance in the hydrological function of peatswamp forest, resulting in drought in the dry season and flooding in the rainy season. In the long dry season, drought also causes forest and land fires on an increasingly scale and frequency.

\subsection{Affected Communities and Losses Due to Degradation of Peat Swamp Forest in South Sumatra}

Drought, floods, forest and peatland fires and haze affect the people who live in the vicinity of peat swamp forests and people who live far from the degraded peat swamp forest area. For people living in villages around peat swamp forest, peat swamp forest degradation causes a decrease in environmental quality because the function of environmental quality protection from peat swamp forest is disturbed.

Assessment of the value of environmental protection is carried out by measuring the effect of changes in environmental quality due to disruption of the function of peat swamp forests as a protector for the surrounding environment. Assessment is carried out by assessing treatment costs, time needed to gettreatment, loss of income due to unhealthy plus medical care costs as a result of disruption of the function of environmental protection from peat swamp forest[11].

The magnitude of the value of environmental protection for each respondent was obtained through interviews with open questions. It is assumed that the community understand the function of protection of peat swamp forest. The discussions with respondents provided information that hydrological disturbances (droughts and floods) and forest and land fires began to occur frequently when peat swamp forest areas began to be disrupted due to deforestation activities. Drought and floods begin to occur when there are logging activities, construction of canals for timber harvesting activities, illegal logging and canal development activities by oil palm plantations. At the study site during the long dry season there was a decrease in water availability and quality, and there was a haze. At the height of the rainy season there is a flood, abundant water with decreased quality. Decreasing environmental quality causes a decrease in the quality of health as indicated by outbreaks of diseases such as vomiting, diarrhea, hives, flu, cough, shortness of breath, fever, malaria and asthma.

There are 92 people ( $43 \%$ of respondents) stated that they did not experience health problems or opportunities due to disruption of the environmental protection function due to the degradation of peat swamp forests which caused drought, floods and haze. A total of 
120 people (57\% of respondents) said they experienced health problems and a loss of some income.

Health problems as a result of drought were not experienced 27 respondents, while 93 respondents experienced health problems. To overcome health problem, 22 people use free drugs purchased at stalls, while 71 people get treatment frommedical personnel (midwives or doctors). In addition to health problems, 58 respondents said there was a decline in income as a result of health problems, while 62 other people did not experience a decrease in income due to drought.

Floods that occur due to peat degradation according to 37 respondents did not cause health problems, while 83 other people said they experienced health problems. Respondents who experienced health problems cope with free drugs (34 people), as many as 47 people overcome with the help of medical personnel, and 2 people overcame the disorder with free drugs and medical assistance. There are 53 respondents experience by decline in income, especially those related to health problems. While 67 other people did not experience a decrease in income due to flooding.

Forest and land fires caused 79 respondents to experience health problems, while 41 respondents did not experience health problems. Respondents who experienced health problems partly overcome with free drugs ( 27 people) while 52 people coped with the help of medical personnel. There are 37 respondents experience by income decline related to health problems. While 83 other people did not experience a decrease in income due to forest and land fires.

The average loss suffered by respondents due to disruption of the function of environmental protection as a result of the degradation of peat swamp forest is $\mathrm{Rp}$. 4.558.887.28 per person per year. The value of environmental quality protection shows that the peat swamp forest area in an undisturbed state can provide protection for the surrounding environment, but degraded peat swamp forest degradationhealth problems, incurs costs to overcome the effects of disturbances, loses some time and income for community around forest.

The area of forest and land burnedin 2015 in South Sumatra Province based on Landsat image data reached 736.587 ha. Forest and land firesin 2000-2016 predominantly occurred in Ogan Komering Ilir (OKI), Musi Banyuasin (Muba) and Banyuasin Regencies. This is allegedly closely related to the presence of peat lands[32]. So, President Decree PP No. 1/ 2016 about Peat Restoration Agency states that OKI and Muba districts are priority restoration districts. Determination of priority restoration is based, among others, on the condition of damaged peat and former forest and land fires in the year 2015.

The area of land and forest that burned during the period June to October 2015 reached 2.6 million hectares at national level. There are about 33 percent of peat land that burns from the total area of land burned. As a result, therewas a haze that covered parts of Indonesia and several surrounding countries, disrupting the transportation, trade and tourismsectors. Schools are closed because the haze also disrupt shealth. The 2015 fires also contribute designificantly to green house gas emissions in Indonesia. National losses due to forest and land firesin 2015 are estimated at Rp 221 trillion (US \$ 16.1 billion)[33].

\section{Conclusion}

Peat swamp forest degradation has an impact on community around forest, provincial and regional communities. Peat swamp forest degradation causes a decrease in environmental quality, productivity and various health impacts on communities around the forest. Various economic sectors such as transportation, transportation, trade, tourism, 
health and education have a negative impact from forest and land fires as a result of peat swamp forest degradation

\section{References}

1. R. Costanza et al., Ecol. Econ 25 (1998)

2. P. Deegen and C. Seegers, Springer, Antiphysiocracy and Pfeiffer, J. G. Backhaue, Ed. New York: Springer (2011)

3. M. Merlo and L. Croitoru, Valuing mediterranean forest towards total economic value (Wallingford, UK.: CABI Publishing, 2005)

4. N. A. Ulya, Peniaian kawasan hutan rawa gabut berdasarkan konsep nilai ekonomi total (studi kasus di Merang Kepayang Sumatera Selatan), Universitas Gadjah Mada (2015)

5. H. Baral, M. R. Guariguata, and R. J. Keenan, Ecosyst. Serv. 22 (2016).

6. R. S. de Groot and P. J. van der Meer, "Quantifying and valuing goods and services provided by plantation forests," in Ecosystem Goods and Services from Plantation Forests ( London, Earthscan, 2010)

7. S. Miura, M. Amacher, T. Hofer, J. San-Miguel-Ayanz, Ernawati, and R. Thackway, For. Ecol. Manage. 352 (2015)

8. M. Kanninen, Plantation forest: global perpectives, " in Ecosystem Goods and Services from Plantation Forests, (J. Bauhaus, P. J. van der Meer, and M. Kanninen, Eds. London, Earthscan, 2010)

9. N. A. Ulya, J. Indones. Econ. Busines, 24, 3 (2009)

10. M. M. Hufschmidt, David E. James, A. D. Meister, B. T. Bower, and J. A. Dixon, Environment, natural systems, and development: an economic valuation guide, 3rd ed. (Baltimore, John Hopkins University Press, 1983)

11. Pusat Penelitian dan Pengembangan Arkeologi Nasional, Permukiman Awal Sejarah di Pantai Timur Sumatera Selatan (Jakarta, 2007)

12. G. Coedẻs, L.-C. Damais, H. Kulke, and P.-Y. Manguin, Kedatuan Sriwijaya Kajian Sumber Prasasti dan Arkeologi (Jakarta, Komunitas Bambu, 2014)

13. S. Yunardy, N. A. Ulya, A. Junaedy, A. Kunarso, J. Harbi, and N. Milantara, Hutan OKI Kembali Lestari Pembelajaran dari Pengelolaan Hutan di Kabupaten OKI Sumatera Selatan. (Palembang, UNSRI Press, 2018)

14. O. W. Wolters, Kebangkitan dan Kejayaan Sriwijaya Abad III-VII, 2nd ed. Depok: Komunitas Bambu (2017)

15. K. Sholeh. J Siddhayatra 22, 2 (2017)

16. Pusat Penelitian dan Pengembangan Arkeologi Nasional, Peradaban Awal Masa Sejarah: Permukiman Awal Masa Sejarah (Pra Sriwijaya) di Pantai Timur Sumatera Selatan, (Jakarta, 2008)

17. Y. Syarofie, Rumah limas: pengaruhnya terhadap arsitektur Indies di Sumatera Selatan (Palembang, Dinas Pendidikan, Sumatera Selatan, 2012)

18. B. B. Utomo, D. Hanafiah, and H. M. Ambary, Kota Palembang: dari Wanua Sriwijaya Menuju Palembang Modern. (Palembang, Pemerintah Kota Palembang, 2012)

19. M. Ikhsan, Berharap Tanggung Jawab Pengusaha HPH untuk Hijaukan Kembali 
Pesisir, (2018)

20. A. Dohong, A. A. Aziz, and P. Dargusch, Land use 69 (2017)

21. J. Miettinen, J. Wang, A. Hooijer, and S. Liew, L. Degrad. Dev 24, 4 (2013)

22. J. Miettinen, C. Shi, and S. C. Liew. Front. Ecol. Environ. 10, 3 (2012)

23. H. M. Gregersen and A. H. Contreras, Economic Analysis of Forestry Project. (Rome, Food and Agricuture Organization, of The United Nations, 1979)

24. U. Chokkalingam et al., Pengelolaan Api, Perubahan Sumberdaya Alam dan Pengaruhnya terhadap Kehidupan Masyarakat di Areal Rawa/Gambut-Sumatera Bagian Selatan (2004)

25. L. P. Koh, R. A. Butler, and C. J. Bradshaw, Front. Ecol. Environ. 7 (2009)

26. A. Hooijer, M. Silvius, H. Woesten, and S. Page, PEAT-CO2. Assessment of CO2 emissions from drained peatlands in SE Asia (2006) 